\title{
Elements of the Historical Cultural Landscape: Mapping Methods and Results in the District of Augsburg
}

\author{
Sophie Grunenberg ${ }^{1} \cdot$ Markus Hilpert $^{1}$
}

Received: 24 September 2020 / Accepted: 1 March 2021 / Published online: 24 March 2021

(c) The Author(s) 2021

\begin{abstract}
Many traces of human cultures and activities over the centuries have marked the landscape, but they are often not recognisable at first glance. The recording and inventory of these historical cultural landscape elements, and their associated mapping, serve to raise awareness of - and ultimately also protect and maintain - the cultural landscape. Researchers at the Chair of Human Geography and Transition Research at the University of Augsburg have recorded all preserved and visible elements of the historical cultural landscape in the district of Augsburg that are not currently under monument or nature protection, and which consequently have not yet been mapped for the corresponding cadastre. In a first step, old maps, aerial and satellite images, local chronicles, regional books and other writings were examined. Subsequently, through public participation instruments, such as information events, individual interviews with local people and a hotline, further historical cultural landscape elements were recorded, based on the knowledge of local citizens. As a result, the three-year project was able to identify a total of 613 cultural remnants of various functions, and these were visualised and saved through numerous maps.
\end{abstract}

Keywords Historical cultural landscape $\cdot$ Monument and nature protection $\cdot$ Inventory $\cdot$ Citizen participation $\cdot$ Mapping

\section{Elemente der historischen Kulturlandschaft: Kartierungsmethoden und Projektergebnisse im Landkreis Augsburg}

\section{Kurzfassung}

Menschen haben über Jahrhunderte hinweg Spuren ihres Handelns und ihrer Kultur in unserer Landschaft hinterlassen, die auf den ersten Blick zum Teil nur schwer zu erkennen sind. Die Erfassung und Inventarisierung solcher historischen Kulturlandschaftselemente und die damit verbundene Kartierung dienen der Bewusstseinsbildung und letztlich auch dem Schutz und Erhalt der Kulturlandschaft. Forscherinnen und Forscher der Universität Augsburg erfassten deshalb alle sichtbaren Elemente der historischen Kulturlandschaft im Landkreis Augsburg, die derzeit nicht unter Denkmal- oder Naturschutz stehen und folglich auch noch nicht für die entsprechenden Kataster kartiert wurden. In einem ersten Schritt wurden alte Karten, Luft- und Satellitenbilder, Ortschroniken, Heimatbücher und andere Schriften gesichtet. Anschließend konnten bei einer Bürgerbeteiligung in Form von mehreren Infoveranstaltungen, durch Einzelinterviews mit Ortskundigen und mit Hilfe einer Hotline zahlreiche weitere historische Kulturlandschaftselemente aus dem Wissen der Bürgerinnen und Bürgern des Landkreises Augsburg erfasst werden. Auf diese Weise gelang es in dem dreijährigen Forschungsprojekt insgesamt 613 Kulturspuren aus unterschiedlichen Funktionsbereichen zu ermitteln, zu kartieren und mit Hintergrundinformationen zu dokumentieren.

Sophie Grunenberg

sophie.grunenberg@geo.uni-augsburg.de

Markus Hilpert

markus.hilpert@geo.uni-augsburg.de

1 Chair of Human Geography and Transition Research, Institute for Geography, University of Augsburg,

86159 Augsburg, Germany 
Schlüsselwörter Historische Kulturlandschaft · Denkmal- und Naturschutz · Inventarisierung · Bürgerbeteiligung · Kartierung

\section{Introduction}

Our current landscape is the result of the long anthropogenic transformation of nature into cultural spaces. How we perceive and interpret such cultural landscapes depends crucially on our knowledge of their individual elements, which we can mentally assemble into a synthesis of the cultural landscape (Kühne and Bruns 2015).

The cultural landscape is therefore defined as the number of individual elements as well as their interpretation. Elements therein are referred to as historical if they (or their remains) have lost their original function, or if such artefacts would no longer be utilised nowadays, due to modern approaches to land use. For such persistent relics, age is thus not a meaningful indicator of characterisation but the absence of their original use. That is why very young objects, such as bomb craters or railway lines, can also be historical elements of the cultural landscape (Gunzelmann 2001).

The statements in this article are based on the results of a three-year research project in the Augsburg district, in which only historical cultural landscape elements were recorded, which were neither under architectural or ground monument protection nor under nature protection. Consequently, cartographic interest focussed on visible landscape artefacts not yet listed in the corresponding cadastre-and therefore without a protection status.

Historical cultural landscape elements, such as old mills, former material pits or boundary stones, are only partially safeguarded by monument or nature protection. Nature protection focuses on the preservation and restoration of natural areas, so relics of human activity are usually not considered in this regard (Hönes 2005; Leicht and Gabel 2005). The main task of monument protection is the recording and conservation of architectural and ground monuments. This includes some cultural landscape elements, but many elements (e.g. orchards meadows, field terraces) are not registered under monument protection (Hönes 2005).

The lack of protection for numerous cultural landscape elements results in the limited interest of spatial planning administrations in mapping and inventorying the cultural landscape. Even though historical cultural landscape elements have already been described in individual and regional scientific literature, and they are mostly known to the inhabitants of the corresponding areas, their systematic and holistic mapping for individual regions has only been carried out in recent years (Büttner 2017; Hilpert and MahneBieder 2016; Stegmann and Reinke 2013). Among others, the cultural landscape cadastre of the Regional Association Frankfurt, Rhine and Main, the digital cultural landscape information system KuLaDig in the Hessian region, the KulturLandschaftsElementeKataster KLEK's in the region around Mecklenburg-Vorpommern as well as the database of the LAG Südlicher Steigerwald e.V. should be mentioned, all of which operate on a voluntary basis.

\section{Aims of the Project}

Intensive land use in modern times increasingly threatens the historic cultural landscape elements. The project for the recording, documentation and presentation of the historical cultural landscape elements in the district of Augsburg started based on the following questions: "Where are historical cultural landscape elements hiding in the district of Augsburg?", "How are these elements distributed?", "How much does the population know about them?" and "How can these historical elements be brought closer to the population?".

The main purposes of the project were thereby to identify and record historical structures, to preserve history in the form of landscape and settlement structures, to make the results tangible for today's inhabitants, and to present an effective instrument for the protection of historically grown structures.

\section{Methodology for Recording the Elements}

This chapter describes the methodological approach of the project in more detail. First of all, the conceptual design and the course of the project are described. Furthermore, some results are presented, and the cartographic visualisation is shown.

\subsection{Conceptual Design}

The cartographic inventory of such landmarks is classified by point, area and line objects in relation to various functions (cf. Table 1).

Our ancestors left traces of the past in our landscape in a variety of ways. These are mainly present in the form of large interventions by agriculture (e.g. terracing) or trade (e.g. quarries), but they can also be seen in evidence of massive buildings representing settlement activity (e.g. bunkers) or linear transport infrastructures (e.g. ravines), that have been preserved from earlier epochs. However, there are also historical cultural landscape elements, such as ridge and furrows or old paths that are only recognisable at second glance 
Table 1 Examples of historical cultural landscape elements

\begin{tabular}{llll}
\hline Function & Punctual & Linear & Extensive \\
\hline Agriculture & Tend trees & Rows of reading stones & Ridge and furrow \\
& Pollard willows & Rows of pollard willows & Field terraces \\
Associative cultural & Boulders & Visual references/axes & Battlefields \\
landscape & Single trees & Routes & Places of work of artists \\
Community life: & Boundary stones & Trenches & Defences \\
religion, state, & Wayside crosses & Pilgrimage routes & Cemeteries \\
military & & & \\
Settlement & Fountain sockets & Row settlements & Deserted villages \\
& Cellar shafts & Fences & Community meadows \\
Leisure time & Dance places & Walkways & Bathing ponds \\
& Viewpoints & Hiking trails & Parks \\
Trade & Mills & Mill ditches & Peat cuttings \\
& Brickworks & Railway lines & Material pits \\
Traffic & Milestones & Sunken roads & Airfields \\
& Fords & Towpaths & Group of old paths \\
\hline
\end{tabular}

Source changed after Klinkhammer (2000) or with the necessary expertise. In some cases, the cultural landscape is also charged with the symbolism relevant to that particular space but which does not physically exist and is therefore not visible, i.e. a historical event that (allegedly) took place at a certain location, of which no visible traces are left today. This phenomenon is known as the 'associative cultural landscape' (BLfH 2013).

\subsection{Systematic Registration of the Historical Cultural Landscape Elements}

As part of the project "Collection, documentation and presentation of elements of the historical cultural landscape in the district of Augsburg", an attempt was made to take an inventory of anthropogenic artefacts in the landscape. Due to its 7,000-year-old settlement history, the district has numerous historical cultural landscape elements that were mapped in the three-year project. The research interest focussed exclusively on anthropogenic and visible elements not yet covered by monument or nature protection. Different empirical procedures were methodologically applied serially.

At the beginning of the investigation, the relevant literature was consulted. Almost 70 works on the district of Augsburg (regional literature, home books, local chronicles, hiking guides, etc.) were evaluated, and 109 historical cultural landscape elements had already been catalogued. However, many local chronicles and hiking guides were written by committed laypeople, so misinterpretations of the landscape cannot be ruled out. Some of the cultural landscape elements mentioned in the literature had already been placed under monument or nature protection, so the numbers of relevant elements from the literature were relatively low compared to other recording methods. The literature is not always up to date either, so some of the described cultural landscape elements have now disappeared. Therefore, the information collected from these sources always had to be carefully checked on site.

In a second step, maps and satellite images were evaluated. Media normally do not contain any further information on conspicuous landmarks, but they do allow for a relatively precise determination of their position in space. While old maps (e.g. the original position sheets from the second half of the nineteenth century) are hardly suitable for the inventory of today's cultural landscape, satellite images prove to be helpful for an initial check as to whether topographic landmarks (e.g. field terraces) are still visible. With the help of airborne laser scans (ALSs), microtopography can even be made visible in forests. Such recordings are achieved by attaching a laser scanner to an airplane or a helicopter and flying over the area to be measured. Meanwhile, the scanner emits a laser beam that is reflected from the surfaces it hits. In this way, sensors measure the distance between the scanner and the object. On the basis of the intensity of the reflected rays, a distinction can be made between the reflections of the treetops and the ground, even in wooded areas. This advantage is used not only to create terrain models, but also to identify smaller topographical elements. To display the soil surface, the measuring points of the treetops are calculated. The results generated by the Bavarian Surveying Administration are easy to interpret.

A third, central component of the methodology was citizen participation. This empirical step was of great importance, because a lot of information about historical relics does not exist in printed form but is stored in the knowledge of the citizens (Gunzelmann 2008; Hilpert and MahneBieder 2017). Therefore, interested people were invited personally and through the local media to six evening events in restaurants in the district. Almost 250 citizens came to these appointments and provided important information and references to previously unrecognised elements of the cultural 


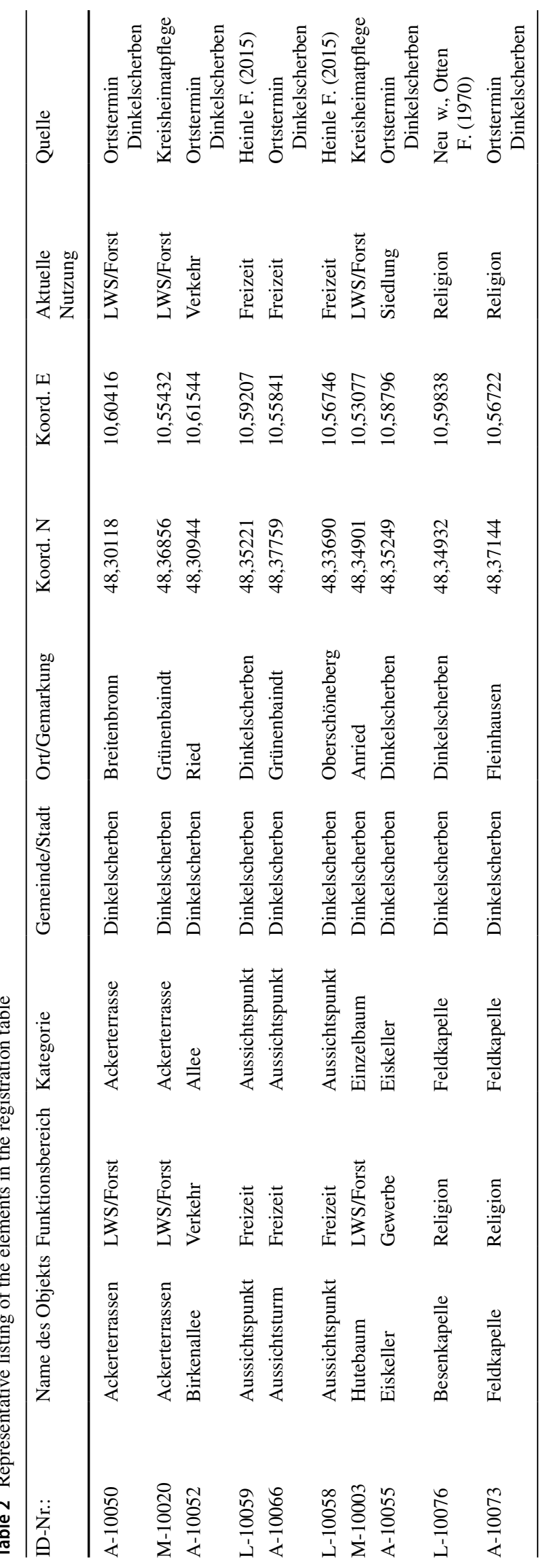

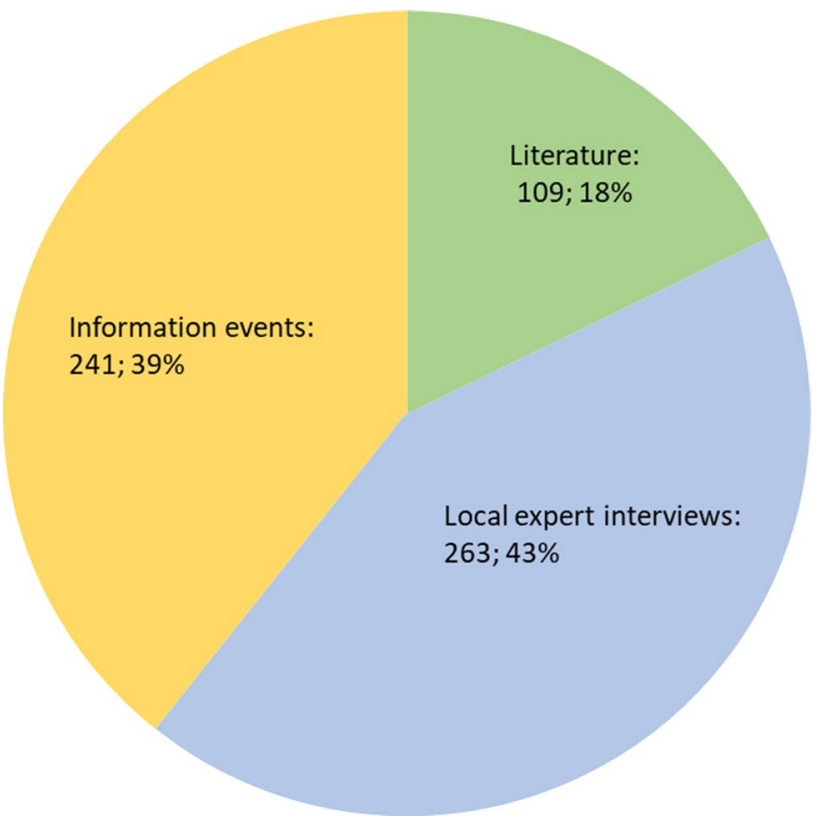

Fig. 1 Source of the recorded cultural landscape elements

landscape, such as ice cellars, bunkers or fords. A previously compiled list of possible cultural landscape elements facilitated these discussions with the citizens, and it enabled many different elements to be recorded that an unstructured conversation might not have captured. A total of 241 cultural traces were not only catalogued at these six events, but also immediately located on the provided maps. In some cases, not only verbal information but also building plans, historical photographs or literature were brought along. The participation events were flanked by an e-mail and a telephone hotline, to involve those people who were interested in the project but could not make the appointments. Intensive press and media work (press, radio and television) in the region supported the project and drew attention to all participation formats.

In a fourth step, more than 30 interviews with so-called 'local experts', i.e. with local personalities who have a good knowledge of their communities (e.g. mayors, foresters, farmers, local maintenance officers), followed in order to verify and supplement the results of public participation. During these discussions, which only addressed sub-areas of the district but in total covered the entire district area, 263 traces of culture that had not yet been recorded by the other methods were further identified. Due to the high level of commitment shown by these respondents, the mentioned traces were often checked together on site after the interviews. 

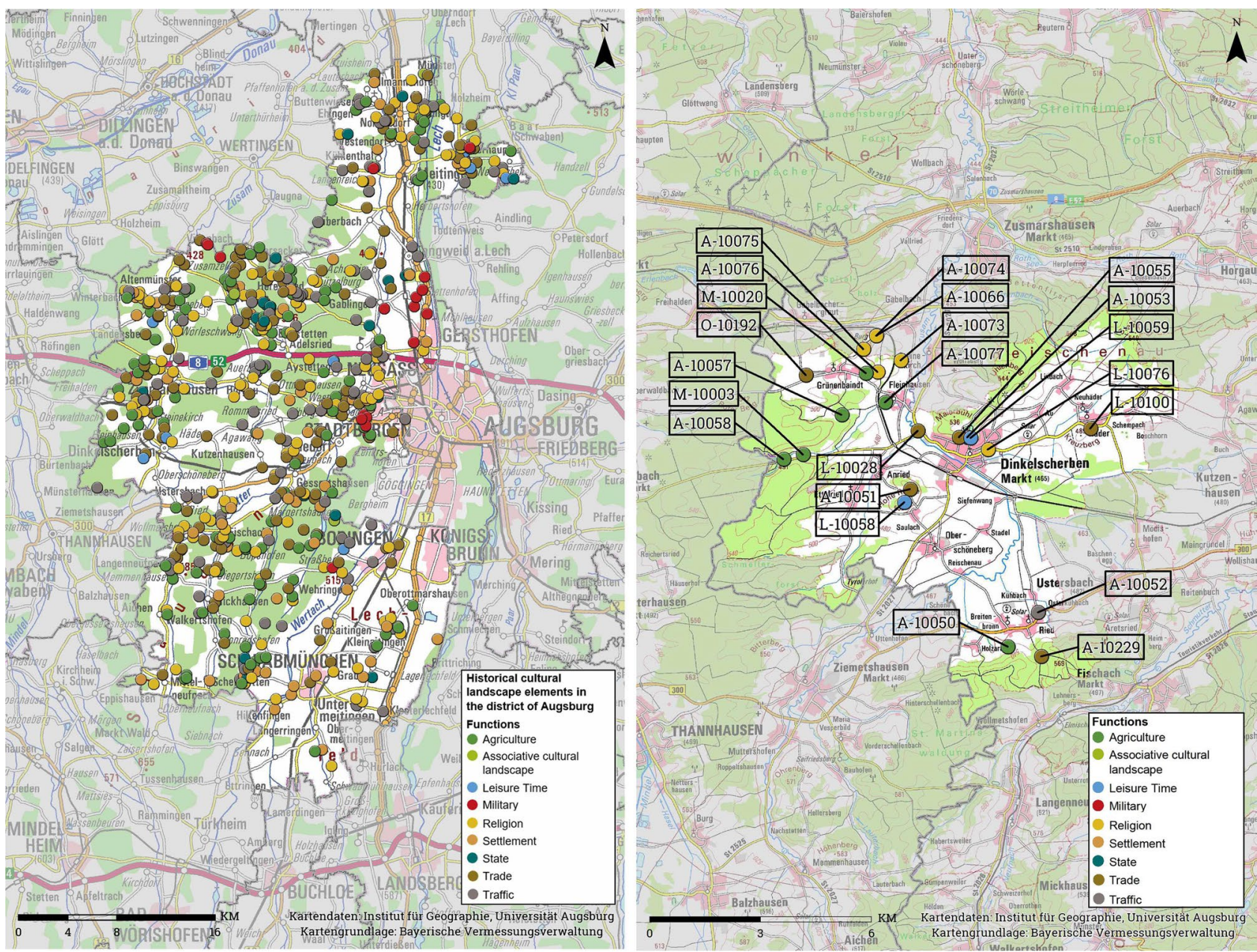

Fig. 2 Cartographic visualisation of the distribution of historical cultural landscape elements in the district of Augsburg and in the municipality of Dinkelscherben

\subsection{Documentation of the Recorded Historical Cultural Landscape Elements}

To systematically record the data obtained in Chapter 3.2, a unified table was created for further processing. Table 2 illustrates the recording of the individual historic cultural landscape elements. For this article, some additional criteria of the elements were not shown in the table for illustrative purposes. The table contains the aspects for Fig. 1 (source of recording), Fig. 2 (exemplary 10 elements of the municipality of Dinkelscherben), Fig. 3 (current functions) and Table 3 (current functions).

In total, 613 historical cultural landscape elements were recorded. None of these has so far been registered in monument or nature protection cadastre, and only a few (109) are mentioned in the literature or in other publications or databases. The great majority (504) of the artefacts are only stored in knowledge of the citizens and local experts, and so the importance of public participation should therefore not be underestimated for the inventory of historical cultural landscape elements (cf. Fig. 1).

\subsection{Cartographic Visualisation}

Two different map types were developed for the visualisation of the results. Figure 2 shows the entire recorded historic cultural landscape elements in the district of Augsburg, with each point representing one element. For the exact localization, the coordinates were determined for each historic cultural landscape element. The different colours indicate the different functions.

A separate map was created for each municipality in the district, to provide a better overview. In addition, the individual elements were numbered to be able to assign further details in Table 2. 


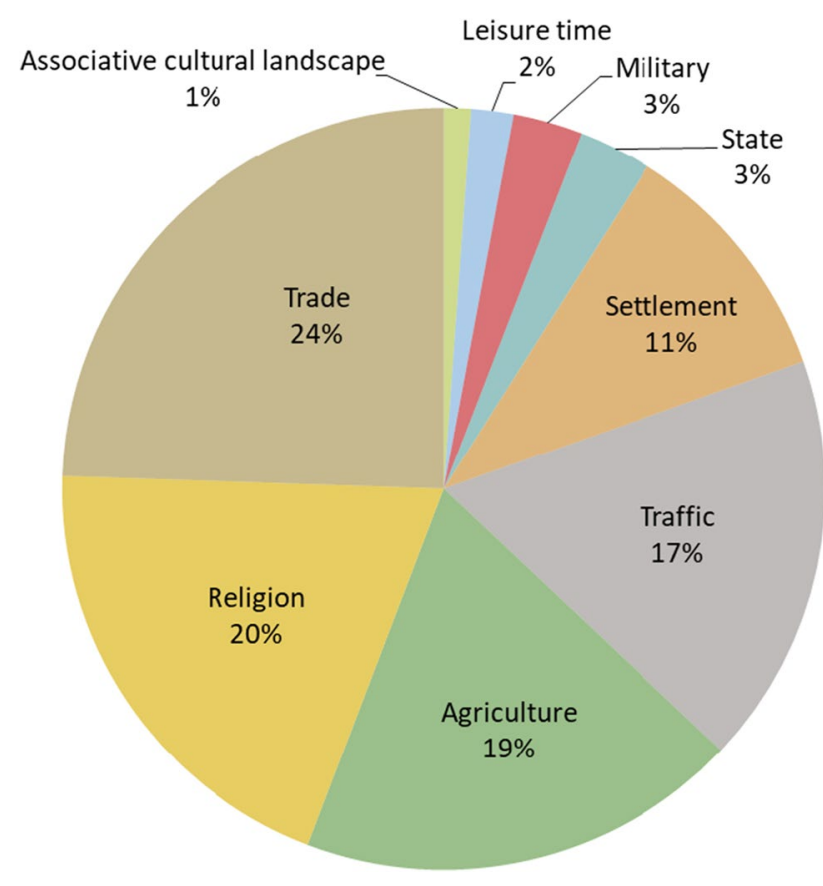

Fig. 3 Original functions of the recorded cultural landscape elements (in \%)

Table 3 Functions of the recorded cultural landscape elements (in \%)

\begin{tabular}{lcc}
\hline Function & Original & Current \\
\hline Agriculture & 18 & 46 \\
Associative cultural landscape & 1 & 0 \\
Leisure time & 2 & 2 \\
Military & 3 & 0 \\
Religion & 19 & 19 \\
Settlement & 11 & 15 \\
State & 3 & 2 \\
Trade & 25 & 3 \\
Traffic & 18 & 13 \\
\hline
\end{tabular}

\section{Results: What Kind of Historical Cultural Landscape Elements were Discovered?}

In the district area, the historical cultural landscape elements are not homogeneously dispersed. In one respect, this can be related either to the knowledge of the involved citizens or to the spatial intensity of their participation in the project; however, it may also be due to the different persistence of the historical cultural landscape in the individual sub-areas. For example, the density of elements in the southern district (Lech and Wertachtal) is significantly below average (cf. Fig. 2), because there is intensive and extensive agriculture (land consolidation). Agricultural landscapes with scant evidence can also be found north of Augsburg in the Lech
Valley, and only a few historical cultural landscape elements were recorded here, except for the northernmost sub-area. The same applies to Reischenau, a relatively flat cleared area in the west of the district.

Meanwhile, density in the northern (Holzwinkel) and southern (Stauden) hilly landscapes, which are largely dominated by forest, is significantly higher. The fact that historical cultural landscape elements are preserved longer in forested areas than in settlement areas or on agricultural land is also confirmed by earlier studies (e.g. Hilpert and Mahne-Bieder 2016).

Sorted according to their functions (cf. Fig. 3), the commercial relics represent the largest group with over a quarter of all recorded cultural landscape elements. This includes very often former sand and clay pits. Sacred cultural landscape elements (e.g. field crosses), relics of former agriculture and forestry (e.g. fish ponds) and historical traffic routes (e.g. sunken paths) follow closely thereafter, while slightly more than every one in ten cultural landscape element results from previous settlement activity (e.g. wells). Artefacts that can be assigned to the function of the state (e.g. border trenches) and the military (e.g. bunker systems) were recorded very rarely. And because people in earlier times had little free time, it is not surprising that a few historical cultural landscape elements (e.g. viewpoints) were identified for this function.

It is also interesting to see in which way the historical cultural landscape elements are used today (cf. Table 3). It is not surprising that sacred cultural landscape elements, such as field crosses, still fulfil their function as religious landmarks; moreover, the majority of historical traffic connections and old routes are still used as paths or roads today, and in some cases, the infrastructure has even been expanded. However, relics from trade (e.g. mills) or leisure time (e.g. bathing ponds) are mostly no longer in use, and in many cases, the corresponding locations and areas are now used for agriculture and forestry.

\section{Conclusion: What Perceptions does the Mapping in the District of Augsburg Provide?}

In summary, it can be said that the project with the large number of participants and a multiple review of the elements enabled a systematic and professional recording.

Mapping in the Augsburg district shows that the methods employed are useful for such investigations, but whilst the five methods have many advantages, they also have minor disadvantages.

The literature analysis provides an initial overview of the historical cultural landscape elements that have already been recorded. The number of preserved elements in the 
literature is very small, which is why the citizen survey is one of the most important recording methods of mapping when seeking to obtain a larger amount of data. Historical elements collected in information events are not totally verifiable beyond doubt, due to often inaccurate oral lore. This method is explicitly accompanied by a review of the terrain models (ALS) of the Bavarian Surveying Administration, to establish any misinterpretations or elements that have already disappeared. Above all, it is essential to collect data through interviews with local experts, who provide valuable information aligned with broad knowledge and accuracy. Only through such interviews is it possible to detect significantly more historical cultural landscape elements; however, they can also be very time-consuming, and district-wide recording would not have been possible in this way within the framework of the project. The hotline, whether via e-mail or telephone, ensures communication with people who are immobile or can only provide some information, and it complements the recording of historical cultural landscape elements in this way.

To map the district as comprehensively and holistically as possible, the mix of methods used for this project was fundamentally necessary, since a single method does not ensure scientific precision or extensive success. The surveys of the historical cultural landscape elements in the Augsburg district provide communities with a tool for future planning in areas such as land use. The awareness and interest of the population is strengthened through various information materials and, in the best case, refreshed and awoken anew.

Funding Open Access funding enabled and organized by Projekt DEAL.

Open Access This article is licensed under a Creative Commons Attribution 4.0 International License, which permits use, sharing, adaptation, distribution and reproduction in any medium or format, as long as you give appropriate credit to the original author(s) and the source, provide a link to the Creative Commons licence, and indicate if changes were made. The images or other third party material in this article are included in the article's Creative Commons licence, unless indicated otherwise in a credit line to the material. If material is not included in the article's Creative Commons licence and your intended use is not permitted by statutory regulation or exceeds the permitted use, you will need to obtain permission directly from the copyright holder. To view a copy of this licence, visit http://creativecommons.org/licenses/by/4.0/.

\section{References}

Büttner T (2017) Kulturlandschaftsinventarisation Steigerwald. Ein Projekt zur Stärkung gelebter Traditionen und des Kulturerbes. In: Bayerischer Landesverein für Heimatpflege e.V. (Hrsg.): Schönere Heimat. Heft 3/2017

Gunzelmann T (2001) Denkmalpflege und historische Kulturlandschaft. In: Vereinigung der Landesdenkmalpfleger in der Bundesrepublik Deutschland (Hrsg.): Arbeitsblätter, Nr. 16. Wiesbaden

Gunzelmann T (2008) Das Spannungsfeld zwischen Expertentum und Ehrenamt bei der Erfassung und der Erhaltung der historischen Kulturlandschaft. In: Bund Heimat und Umwelt in Deutschland (Hrsg.): Kulturlandschaftliche Informationssysteme in Deutschland. Bonn, S. 116-122

Hilpert M, Mahne-Bieder J (2016) Inventarisierung der historischen Kulturlandschaft. Methoden und Ergebnisse einer Bestandsaufnahme im Wittelsbacher Land. In: Natur und Landschaft. Heft 8/2016, S. 366-373

Hilpert M, Mahne-Bieder J (2017) Kartierung der historischen Kulturlandschaft. Eine kritische Evaluation der Inventarisierungsmethoden. In: Kartographische Nachrichten. Heft 1/2017, S. 23-26

Hönes E-R (2005) Historische Kulturlandschaft zwischen allen Stühlen? In: Bayerischer Landesverein für Heimatpflege e.V. (Hrsg.): Historische Kulturlandschaft - Erhalt und Pflege. München, S. $35-58$

Klinkhammer B, Peters J (2000) Kulturhistorische landschaftselemente: systematisieren, kartieren und planen-Untersuchungen in Brandenburg. Naturschutz und Landschaftsplanung Heft 5(2000):147-152

Kühne O, Bruns D (2015) Gesellschaftliche transformation und die entwicklung von landschaft. Eine betrachtung aus der perspektive der sozialkonstruktivistischen landschaftstheorie. In: Kühne O, Gawronski K, Hernik J (Hrsg.) Transformation und Landschaft. Die folgen sozialer Wandlungsprozesse auf Landschaft. Wiesbaden, S. 17-34

Bayerische Landesverein für Heimatpflege (BLfH) (Hrsg.) (2013) Handbuch der historischen Kulturland-schaftselemente in Bayern. München, S. 9-36

Leicht H, Gabel G (2005) Historische kulturlandschaft—naturschutz und landschaftspflege. In: Bayerischer Landesverein für Heimatpflege e.V. (Hrsg.): Historische Kulturlandschaft-Erhalt und Pflege. München, S. 17-22

Stegemann V, Reinke M (2013) Bürger im Einsatz für die Kulturlandschaft. Modell einer ehrenamtlichen Kulturlandschaftserfassung. In: Bayerischer Landesverein für Heimatpflege e.V. (Hrsg.) Schönere Heimat. Heft 1/2013, S. 24-32 